\title{
Prenatal Diagnosis of Clubfoot: A Review of Current Available Methodology
}

\section{Cesare Faldini ${ }^{1}$, Domenico Fenga ${ }^{2}$, Ilaria Sanzarello ${ }^{2}$, Matteo Nanni ${ }^{1}$, Francesco Traina ${ }^{1}$, Michele Attilio A. Rosa ${ }^{2}$}

${ }^{1}$ Rizzoli Orthopaedic Institute, University of Bologna, Italy

${ }^{2}$ Department of Orthopaedics and Traumatology, Department of Biomedical Sciences and Morphological and Functional Images, University of Messina, Italy

\section{Correspondence:}

Michele Attilio A. Rosa, Department of Orthopaedics and Traumatology, Department of Biomedical Sciences and Morphological and Functional Images, Universita degli Studi di Messina, Via Consolare Valeria n 1, Messina, ME 98100, Italy

E-mail:mattilio51@gmail.com Tel: +390902213040

Received: 29 July 2016

Accepted: 29 Nov 2016

Published Online: 05 April 2017

Published: 29 Sep 2017

Key words: clubfoot, ultrasound, prenatal diagnosis, congenital deformities

Citation: Faldini C, Fenga $D_{\text {, }}$ Sanzarello I, Nanni M, Traina F, Rosa MAA. Prenatal diagnosis of clubfoot: a review of current available methodology.

Folia Medica 2017;59(3):247-253 doi: 10.1515/folmed-2017-0030
Background: Clubfoot is one of the most common congenital limb deformities. Prenatal diagnosis of the condition is essential as it can help treat the malformation as early as possible. We reviewed the recent available literature concerning the current methods for prenatal diagnosis of clubfoot.

Methods: The following databases were searched from 1966 to 2015: PubMed, OVID, Cochrane, CINAHL, Google scholar and Embase.

Results: Out of a total number of 197 retrieved articles, after abstract or title page evaluation, 158 articles not matching the inclusion criteria were excluded. The full text versions of the remaining 39 articles were obtained, and their reference lists screened, with the addition of another 5 full-text articles.

Conclusions: Currently, ultrasonography is considered the most reliable method of prenatal diagnosis of clubfoot. Ultrasonographic diagnosis of clubfoot appears more likely between the 18th and the 24th week of pregnancy. Alternative imaging is not indicated. There is no agreement whether to propose foetal karyotyping when isolated clubfoot is diagnosed by prenatal ultrasonography. Early detection of clubfoot should prompt a careful surveillance during pregnancy in order to detect any possible additional abnormalities and, if any of these are detected, invasive testing should be offered.

\section{INTRODUCTION}

Clubfoot, also known as congenital talipes equinovarus, is one of the most common congenital limb deformities. It occurs in 1 to 3 per thousands of live births with a 2:1 male to female ratio and it is bilateral in approximately half of cases. ${ }^{1,2}$ Although most clubfeet are idiopathic, some are associated with chromosomal abnormalities (i.e. $4 p$ deletion, $18 \mathrm{q}$ deletion, trisomy 13 or trisomy 21 ), genetic syndromes, or family history.

Prenatal diagnosis of clubfoot is helpful in planning the treatment at birth but it should be as accurate as possible; a misdiagnosis can cause an excessive stress to the parents and it could lead to unnecessary invasive testing. It has been demonstrated that expecting mothers prefer to know in advance the possible diagnosis of clubfoot rather than find out at birth. Besides, a prenatal diagnosis of clubfoot gives the parents the opportunity to know in advance about the treatment and prognosis, including prenatal counselling services, and this may allow clinicians to set up their network for an optimal disease management. ${ }^{3,4}$

Furthermore, a considerable number of malformations have been associated with clubfoot such as cleft lip and palate, micrognathia, congenital heart defect, hydrocephalus, myelomeningocele, and other structural abnormalities. ${ }^{5-7}$ Considering this, prenatal diagnosis can lead to the diagnosis of other associated deformities and, in some cases, of chromosomal abnormalities compatible or incompatible with extra-uterine life. 
Currently, ultrasonography is the most used method of prenatal diagnosis of clubfoot. Ultrasound has been used to detect fetal abnormalities since the early 1980 s, even if it was not initially considered detailed enough to diagnose clubfoot. Indeed, the use of prenatal ultrasonography for clubfoot detection has increased only during the last decade. ${ }^{8,9}$ The frequent use of ultrasound examination, combined with technological improvement, has allowed an early diagnosis for many diseases. ${ }^{3}$ Clubfoot is typically detected in approximately $60 \%$ of cases in the prenatal period and the detection rate is increasing. ${ }^{10}$

However, the accuracy of this examination is dependent on many factors, such as experience of the physician, gestational age, the quality of equipment and the methodology used. ${ }^{11}$

There are some studies on magnetic resonance imaging used for prenatal diagnosis of clubfoot $^{12}$, however, MRI effects on the developing fetus are not clear, hence routine MRI is probably not justified, especially in case of isolated clubfoot. ${ }^{13}$ Today it is unclear whether it is necessary to perform further diagnostic tests, such as amniocentesis or chorionic villus sampling (CVS). Considering the important role of prenatal diagnostic testing of clubfoot, we performed a review of the recent available literature on prenatal diagnosis of clubfoot.

\section{AIM}

The aim of this study was to determine the actual usefulness of prenatal diagnosis of clubfoot, evaluate the available current methods and the effectiveness of the major prenatal tests.

\section{METHODS}

\section{LITERATURE SEARCHING AND DATA COLLECTION}

A review of the literature was performed in a systematic fashion using the preferred reporting items for systematic reviews and meta-analyses (PRISMA) checklist and algorithm. ${ }^{14}$ The following databases were searched between 1966 and 2015: PubMed (http://www.ncbi.nlm.nih.gov/sites/entrez/), OVID (http://www.ovid.com), Cochrane (http:// www.cochrane.org/reviews/), CINAHL, Google scholar and Embase. All journals were considered, but only English papers were included. Literature reviews, instructional courses, surgical techniques and letters to the editors were excluded. The following keywords were combined together to perform the research: 'clubfoot' or 'talipes' combined with 'prenatal diagnosis', 'ultrasound', 'MRI', 'amniocentesis', 'chorionic villus sampling'. All potentially eligible articles were retrieved, and their references were assessed to identify further relevant articles, including reviews and meta-analyses.

\section{RESULTS}

Out of a total number of 197 retrieved articles, after title page and abstract evaluation, 158 were excluded because they did not match the inclusion criteria. The full-text versions of the remaining 39 articles were obtained and their reference lists screened. Five full-text articles were consequently added (Fig. 1). Out of 44 articles, 17 were excluded be-

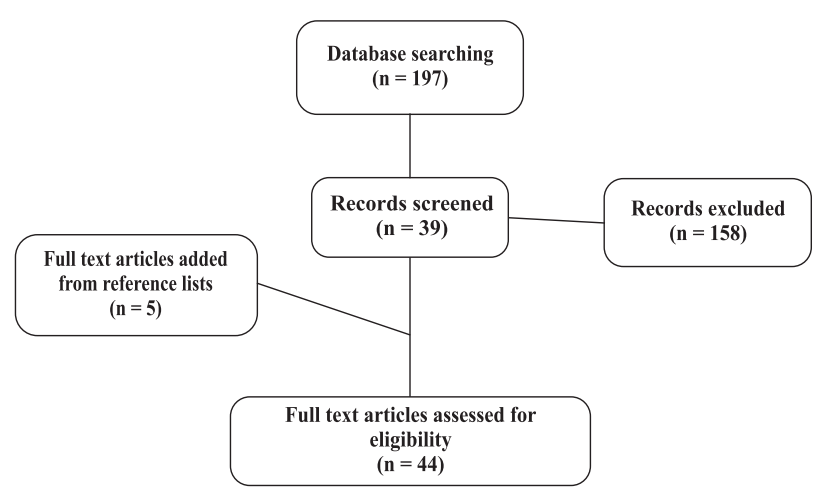

Figure 1. Flowchart of literature review.

cause they did not conform to the aim of the present review, leaving 27 articles for the study (Table 1).

\section{DISCUSSION}

Different authors highlighted the utility of prenatal diagnosis of clubfoot for clinical, therapeutic and socio-economic concerns. ${ }^{15,16}$ Clubfoot can also be associated with other conditions that can result in severe or permanent disability or even premature death $^{2}$; for this reason, it is of utmost importance that we should differentiate isolated from complex clubfoot. On the other hand, during counselling, it is important to adequately inform parents about the limits of prenatal diagnosis. ${ }^{17}$

Ultrasound has become a routine procedure during pregnancy and it can be performed by transabdominal (TAS) or transvaginal (TVS) approach. ${ }^{13}$ In the early stages of gestation, TVS examination provides better image resolution and this can also allow us to find musculoskeletal abnormalities earlier than 14th to 16 th week of pregnancy. However, with the progress of pregnancy, TVS becomes less useful because of the foetus displacement away from the vaginal canal. Therefore TAS is considered more suitable after the 16th week of pregnancy. ${ }^{11-13}$

The limb buds are first seen on TVS ultrasound 
Table 1. List of selected references

\begin{tabular}{|c|c|c|c|c|c|}
\hline \multirow[t]{2}{*}{ Ref. } & \multirow[t]{2}{*}{ Author } & \multirow[t]{2}{*}{ Year } & \multicolumn{3}{|c|}{ Diagnostic Procedure } \\
\hline & & & Ultrasound & MRI & $\begin{array}{c}\text { Amniocentesis/ } \\
\text { karyotyping }\end{array}$ \\
\hline 1 & Servaes S & 2010 & - & • & \\
\hline 2 & Nemec U & 2012 & & $\bullet$ & \\
\hline 3 & Lauson $\mathrm{S}$ & 2010 & - & & • \\
\hline 4 & Hartge DR & 2012 & - & & \\
\hline 5 & Bakalis $\mathrm{S}$ & 2002 & • & & \\
\hline 6 & Cohen-Overbeek TE & 2006 & $\bullet$ & & • \\
\hline 7 & Glotzbecker MP & 2010 & • & & \\
\hline 8 & Mahan ST & 2014 & - & & \\
\hline 9 & Radler C & 2011 & $\bullet$ & & \\
\hline 10 & Woodrow N & 1998 & • & & \\
\hline 11 & Liao $\mathrm{H}$ & 2012 & • & & \\
\hline 12 & Sharma R & 2011 & • & & \\
\hline 13 & Canto MJ & 2008 & • & & • \\
\hline 14 & Ryu JK & 2003 & - & & \\
\hline 15 & Mammen L & 2004 & • & & • \\
\hline 16 & Malone FD & 2000 & • & & • \\
\hline 17 & Offerdal $\mathrm{K}$ & 2007 & • & & \\
\hline 18 & Shipp TD & 1998 & $\bullet$ & & - \\
\hline 19 & Tillett RL & 2000 & • & & \\
\hline 20 & Tredwell SJ & 2001 & - & & • \\
\hline 21 & Woodrow N & 1998 & • & & • \\
\hline 22 & Keret D & 2002 & • & & \\
\hline 23 & Pullinger $\mathrm{M}$ & 2014 & • & & \\
\hline 24 & Kul S & 2012 & & - & \\
\hline 25 & Bar-On E & 2005 & & & $\bullet$ \\
\hline 26 & Rijhsinghani A & 1998 & & & - \\
\hline 27 & Pagnotta G & 1996 & • & & - \\
\hline
\end{tabular}

at about 8th week of gestation and the long bones are visible by the 11 th week; ${ }^{13}$ when legs and foot sole do not appear perpendicular to each other it can be possible to infer clubfoot diagnosis ${ }^{18}$. The embryonic and foetal foot are reported to develop in two phases, the fibular (6.5 - 7 gestation weeks) and the tibial ( 8 - 9 gestation weeks). ${ }^{19}$ During these two stages of development, the foot passes through three positions: at first it is located in a straight line with the leg (initial position); subsequently it is posed in a marked position of equinovarusadduct (embryonic phase), and finally, around the 11th week of gestation, it assumes its final physiological position (foetal phase). ${ }^{7}$ If any foot alterations are observed at an earlier stage, a tight compulsory ultrasound control becomes necessary 
before the final diagnosis of clubfoot. However, even when the clubfoot is not detected early, late onset development can still occur. ${ }^{10}$ The late-onset and very late-onset clubfoot may be diagnosed late because of false-negative results within the earlier scans. For this reason, scans performed around the 20th - 24th week seems to be the most reliable to confirm or exclude clubfoot diagnosis. ${ }^{11}$ Anyway, regarding the clubfoot, ultrasound have proven to be the most reliable method of prenatal diagnosis. ${ }^{9,10,15,18,20-24}$ The ability of achieving prenatal diagnosis of clubfoot have increased during the past two decades from about $25 \%$ to over $80 \%$. Reports about the risk of false-positive prenatal diagnosis during pregnancy are diverse: the rate of false-positive prenatal diagnosis vary widely from 0 to $40 \%$ in isolated clubfoot. ${ }^{20,25-28}$ Nevertheless, there seems to be a smaller percentage (below 10\%) of false-positive rate when prenatal detection of clubfoot is performed in specialized centers with targeted anatomic ultrasound survey. ${ }^{17}$

Keret et al. ${ }^{11}$ in 2002 identified three types of clubfoot according to the gestational age: an early clubfoot if diagnosed by the 12th to 17 th week of gestation, a late clubfoot if diagnosed between the 18 th and the 24th week of gestation, and a very late clubfoot if diagnosed after the 25th week of gestation. However, despite the fact that many reports are in agreement with the effective use of ultrasound for prenatal diagnosis of clubfoot, a systematic analysis of the literature shows no clear evidence on the correlation between the earliness of ultrasound examination and the severity of the malformation of the foot. Ultrasound analysis is therefore unable to assist the paediatric orthopaedic surgeon in prenatal counselling. ${ }^{19}$ Nevertheless, Pullinger et al recently reported that clubfoot found on fetus between the 18 th and the 20th week of pregnancy with ultrasonography scans will develop a structural deformity requiring treatment in $81 \%$ of the cases. ${ }^{29}$

Ultrasound examination is undoubtedly considered the only effective screening examination during the entire period of gestation. It is indeed a safe, inexpensive and easy to perform examination. ${ }^{29}$ However, ultrasound examination depends on physician skills and, moreover, the result may be affected by certain conditions such as fetus position, maternal obesity, bones overlapping and oligoidramnios. For these reasons, magnetic resonance imaging (MRI) examination has been proposed by some authors. ${ }^{30,31}$ This procedure, without using ionizing radiation has been demonstrated to be safe for the foetus. More- over it has excellent tissue contrast, exam results are not operator-dependent and it is not influenced by external factors such as obesity of the mother or oligohydramnios. Furthermore, new scanning systems allow fast elimination of movements artefacts ensuring a good test result within the second and third trimester. However, it is still unclear what effect MRI has on the developing foetus; for this reason, some authors argue that offering MRI as routine examination is not justified. ${ }^{13,30}$

Although idiopathic in the majority of cases, clubfoot could be sometimes associated with chromosomal abnormalities, genetic syndromes or other deformities. Historically, a sonographic diagnosis of clubfoot was considered an indication for amniocentesis, though recent studies have suggested karyotyping only if associated anomalies on the sonographic survey are presents. ${ }^{17}$ In a recent review of the literature, it was reported that the risk of foetal aneuploidy was between $1.7 \%$ and $3.6 \%$ in case of isolated clubfoot. ${ }^{2}$ Currently, there is not enough evidence supporting the analysis of foetal karyotype when clubfoot is detected at ultrasonography. ${ }^{25}$ Shipp and Benacerraf ${ }^{26}$ examined 68 foetuses with a prenatal diagnosis of congenital clubfoot; four of these had aneuploidy which led the authors to recommend the assessment of foetal karyotype in all cases of isolated clubfoot. However, two of these four cases were related to sex chromosomal abnormalities (47 XXY and $47 \mathrm{XXX)}$ ) and therefore should be considered as a random finding because the clubfoot is not part of the phenotype of these syndromes. The two other chromosomal abnormalities were trisomy 21 and 18 - in these cases, too, the clubfoot should be considered a random artefact, because it is not counted among the phenotypic characteristics of these syndromes, in addition, both syndromes are easily detectable with the prenatal ultrasound.

Rijhsinghani et al. ${ }^{19}$ studied seven of 35 patients with isolated clubfoot. Follow-up beyond their first year of life revealed that three of seven cases developed other abnormalities, previously not suspected in the foetal period. All these three cases had bilateral clubfeet. Leaving out the only false-positive case of isolated clubfoot, which was recognized as normal on follow-up ultrasound examination, three of six isolated cases of clubfoot were diagnosed with serious neuromuscular disorders in the neonatal period, one with moderate cerebral atrophy and cerebral palsy and two with arthrogryposis. The three foetuses with true isolated clubfoot (no other anomalies detected 
ante- or post-natally) had a family history that included clubfoot. Based on these results the authors recommended that karyotype evaluation should be performed in all cases of clubfoot.

Offerdal et al. ${ }^{8}$ evaluated clubfoot detection in a large non-selected population and studied the prevalence and outcome of isolated clubfoot and cases with associated anomalies. Of 113 patients, 55 had an isolated clubfoot, 27 diagnosed before birth. Despite not reporting the percentage of postnatal abnormalities associated with isolated clubfoot, the authors suggested that karyotyping should be done in all suspected cases of isolated clubfoot, since not all foetuses with chromosomal aberrations present structural anomalies. Pagnotta et al. ${ }^{32}$ showed that out of 27 foetuses affected by clubfoot (41 feet) diagnosed at ultrasonography in the third trimester of pregnancy, only 8 (14 feet) had an isolated clubfoot (6 bilateral, 2 unilateral). Hence, ultrasound diagnosis of clubfoot should lead to doing amniocentesis as it may be associated with an abnormal karyotype in a high percentage of cases. However, a recent report by the Canadian Early and Mid-Trimester Amniocentesis Trial Group (CEMAT) suggests that we should stop using the routine early amniocentesis as a diagnostic test due to the high incidence of foot deformities or foetal damages in cases of early amniocentesis compared to those who were not subjected to this procedure. ${ }^{28}$ The authors reported a statistically significant difference between the incidence of foot deformities in case of early amniocentesis (1.63\%) compared with mid-trimester amniocentesis $(0.12 \%)$. They ascribed this phenomenon to the reduction of amniotic fluid resulting from amniocentesis, describing how the early exam $(11+0$ to $12+6$ gestational weeks $)$ statistically affects the development of clubfoot. ${ }^{20}$ Considering this, it is likely to incur in a "ripple effect" 28 : since early amniocentesis has been found to be associated with olygoidramnios and this has been found to be related to clubfoot, we might be persuaded to suspect that early amniocentesis could be related to the clubfoot development, rather than allow an early deformity detection. Other authors found no pathological karyotypes in those foetuses with isolated clubfoot. Bar-on E et al. ${ }^{17}$ have carried out a study on the analysis of the karyotype in 25 pregnancies. Karyotypes showed that only three foetuses with clubfoot had additional malformations that did not affect the decision-making process on future treatment. Similar conclusions were made by Woodrow et al. ${ }^{20}$ after finding no cases of abnormal foetal karyotypes in a series of 17 foetuses with isolated clubfoot. Also, Malone et al. ${ }^{25}$, studying 51 isolated clubfoot, did not find any cases of aneuploidy on foetal karyotype or new-born examination. These discordant reports puzzle over the actual need to perform invasive exams, such as amniocentesis, in absence of other risk factors associated with clubfoot.

\section{CONCLUSIONS}

Prenatal diagnosis of clubfoot is considered useful in early detection of the deformity and subsequently leads to parents' counselling and the treatment at birth. Prenatal ultrasonography has been used increasingly in the last decade to detect clubfoot, and currently, ultrasound study is the most reliable method of prenatal diagnosis of clubfoot, even though the accuracy of this method is dependent on several factors such as the skills of the examiner, the quality of the equipment, the methodology used, and the gestation period. Since the normal relationship between foot and leg is generally reached by the 11th week of pregnancy, ultrasonographic screening can already detect the presence of clubfoot after this period. Nevertheless, ultrasonographic diagnosis of clubfoot appears more likely between the 18th and the 24th week of pregnancy.

Alternative imaging is not indicated. MRI may show foot abnormalities in details and it is not dependent on the skills of operator. However, as the effects of MRI on the developing foetus are not sufficiently well-studied, and considering the acceptable accuracy of ultrasonography, routine MRI is not advised for prenatal diagnosis of clubfoot.

There is no agreement whether to do foetal karyotyping when isolated clubfoot is diagnosed by prenatal ultrasonography. Anyway, early detection of clubfoot should prompt a careful surveillance during pregnancy in order to notice any possible additional abnormalities. If any of these are detected, or if women have any other standard indications for foetal karyotype analysis, such as advanced maternal age, invasive testing should be offered. In summary, karyotype analysis is mainly useful in the early diagnosis of general diseases when the ultrasound-diagnosed clubfoot can represent one of their manifestations. Whereas, regarding specifically the clubfoot, in case of isolated idiopathic deformity, karyotype analysis by amniocentesis seems not to provide further essential data concerning diagnosis and treatment, even if it may allow a greater characterization of the deformity when developed, for 
example, in genetic syndromes, and thus provide additional prognostic information.

\section{REFERENCES}

1. Wynne-Davies R. Family studies and the cause of congenital club foot. Talipes equinovarus, talipes calcaneo-valgus and metatarsus varus. J Bone Joint Surg Br 1964;46:445-63.

2. Yamamoto H. A clinical, genetic and epidemiologic study of congenital club foot. Jinrui Idengaku Zasshi 1979;24:37-44.

3. Mahan ST, Yazdy MM, Kasser JR, et al. Prenatal screening for clubfoot: what factors predict prenatal detection? Prenat Diagn 2014;34:389-93.

4. Miller PR, Kuo KN, Lubicky JP. Clubfoot deformity in Down's syndrome. Orthopedics 1995;18:449-52.

5. Bronshtein M, Liberson A, Lieberson S, et al. Clubfeet associated with hydrocephalus: new evidence of gradual dynamic development in utero. Obstet Gynecol 1992;79:864-7.

6. Plotkin S, Cann RP, Valmassy RL. In utero fetal lower extremity examination by diagnostic ultrasound. J Am Podiatr Med Assoc 1988;78:287-91.

7. Bar-Hava I, Bronshtein M, Orvieto R, et al. Caution: prenatal clubfoot can be both a transient and a lateonset phenomenon. Prenat Diagn 1997;17:457-60.

8. Offerdal K, Jebens N, Blaas HG, et al. Prenatal ultrasound detection of talipes equinovarus in a nonselected population of 49314 deliveries in Norway. Ultrasound Obstet Gynecol 2007;30:838-44.

9. Radler C, Myers AK, Burghardt RD, et al. Maternal attitudes towards prenatal diagnosis of idiopathic clubfoot. Ultrasound Obstet Gynecol 2011;37:658-62.

10. Canto MJ, Cano S, Palau J, et al. Prenatal diagnosis of clubfoot in low-risk population: associated anomalies and long-term outcome. Prenat Diagn 2008;28:343-6.

11. Keret D, Ezra E, Lokiec F, et al. Efficacy of prenatal ultrasonography in confirmed club foot. J Bone Joint Surg Br 2002;84:1015-9.

12. Servaes S, Hernandez A, Gonzalez L, et al. Fetal MRI of clubfoot associated with myelomeningocele. Pediatr Radiol 2010;40:1874-9.

13. Nemec U, Nemec SF, Kasprian G, et al. Clubfeet and associated abnormalities on fetal magnetic resonance imaging. Prenat Diagn 2012;32(9):822-8.

14. Liberati A, Altman DG, Tetzlaff J, et al. The PRISMA statement for reporting systematic reviews and meta-analyses of studies that evaluate health care interventions: explanation and elaboration. J Clin Epidemiol 2009;62:e1-34.

15. Lauson S, Alvarez C, Patel MS, et al. Outcome of prenatally diagnosed isolated clubfoot. Ultrasound
Obstet Gynecol 2010;35:708-14.

16. Hartge DR, Gaertner S, Weichert J. Prenatal detection and postnatal outcome of congenital talipes equinovarus in 106 fetuses. Arch Gynecol Obstet 2012;286:831-42.

17. Bar-On E, Mashiach R, Inbar O, et al. Prenatal ultrasound diagnosis of club foot: outcome and recommendations for counselling and follow-up. $\mathrm{J}$ Bone Joint Surg Br 2005;87:990-3.

18. Ryu JK, Cho JY, Choi JS. Prenatal sonographic diagnosis of focal musculoskeletal anomalies. Korean J Radiol 2003;4:243-51.

19. Rijhsinghani A, Yankowitz J, Kanis AB, et al. Antenatal sonographic diagnosis of club foot with particular attention to the implications and outcomes of isolated club foot. Ultrasound Obstet Gynecol 1998;12:103-6.

20. Woodrow N, Tran T, Umstad M, et al. Mid-trimester ultrasound diagnosis of isolated talipes equinovarus: accuracy and outcome for infants. Aust N Z J Obstet Gynaecol 1998;38:301-5.

21. Liao H, Cai A, Wang B, et al. Value of the fetal plantar shape in prenatal diagnosis of talipes equinovarus. J Ultrasound Med 2012;31:997-1002.

22. Sharma R, Stone S, Alzouebi A, et al. Perinatal outcome of prenatally diagnosed congenital talipes equinovarus. Prenat Diagn 2011;31:142-5.

23. Glotzbecker MP, Estroff JA, Spencer SA, et al. Prenatally diagnosed clubfeet: comparing ultrasonographic severity with objective clinical outcomes. J Pediatr Orthop 2010;30:606-11.

24. Mammen L, Benson CB. Outcome of fetuses with clubfeet diagnosed by prenatal sonography. J Ultrasound Med 2004;23:497-500.

25. Malone FD, Marino T, Bianchi DW, et al. Isolated clubfoot diagnosed prenatally: is karyotyping indicated? Obstet Gynecol 2000;95:437-40.

26. Shipp TD, Benacerraf BR. The significance of prenatally identified isolated clubfoot: is amniocentesis indicated? Am J Obstet Gynecol 1998;178:600-2.

27. Tillett RL, Fisk NM, Murphy K, et al. Clinical outcome of congenital talipes equinovarus diagnosed antenatally by ultrasound. J Bone Joint Surg Br 2000;82:876-80.

28. Tredwell SJ, Wilson D, Wilmink MA, et al. Mid-trimester amniocentesis trial $\mathrm{G}$, the Canadian pediatric orthopedic review G. Review of the effect of early amniocentesis on foot deformity in the neonate. $\mathrm{J}$ Pediatr Orthop 2001;21:636-41.

29. Pullinger M, Southorn T, Easton V, et al. An evaluation of prenatal ultrasound screening for CTEV: accuracy data from a single NHS University Teaching Hospital. Bone Joint J 2014;96-B:984-8.

30. Kul S, Korkmaz HA, Cansu A, et al. Contribution of MRI to ultrasound in the diagnosis of fetal anoma- 
lies. J. Magn Reson Imaging 2012;35:882-90.

31. Bulas D. Fetal magnetic resonance imaging as a complement to fetal ultrasonography. Ultrasound Q 2007;23:3-22.
32. Pagnotta G, Maffulli N, Aureli S, et al. Antenatal sonographic diagnosis of clubfoot: a six-year experience. J Foot Ankle Surg 1996;35:67-71.

\title{
Пренатальная диагностика косолапости: обзор имеющейся на данный момент методологии
}

\author{
Чезаре Фалдини ${ }^{1}$, Доменико Фенга ${ }^{2}$ Илария Санзарело ${ }^{2}$, Матео Нани ${ }^{1}$, \\ Франческо Траина ${ }^{1}$, Микеле Аттилио А. Роса ${ }^{2}$ \\ ${ }^{1}$ Институт ортопедии Ризоли, Болонский университет, Италия \\ 2 Кафедра ортопедии и травматологии, Кафедра биомедицинских наук и морфологических и функциональных изобра- \\ жений, Университет Месины, Италия
}

Адрес для корреспонденции: Микеле Аттилио А. Роса, Кафедра ортопедии и травматологии, Кафедра биомедицинских наук и морфологических и функциональных изображений, Университет Месины, Via Consolare Valeria n 1, Месина, ME 98100 Италия

E-mail:mattilio51@gmail.com Тел.: +390902213040

Дата получения: 29 июля 2016 Дата приемки: 29 ноября 2016 Дата онлайн публикации: 05 апреля 2017

Дата публикации: 29 сентября 2017

Ключевые слова: косолапость, ультразвук , пренатальная диагностика, врождённые деформации

\section{Образец цитирования:}

Faldini C, Fenga D, Sanzarello

I, Nanni M, Traina F, Rosa MAA.

Prenatal diagnosis of clubfoot:

a review of current available

methodology.

Folia Medica 2017;59(3):247-253. doi: 10.1515/folmed-2017-0030
Введение: Косолапость является одной из наиболее часто встречающихся врождённых деформаций конечностей. Пренатальная диагностика важна тем, что предлагает возможность раннего лечения. Нами была рассмотрена имеющаяся на данный момент литература, связанная с актуальными методами пренатальной диагностики косолапости.

Методы: Были рассмотрены следующие базы данных за период 1966-2015: PubMed, OVID, Cochrane, CINAHL, Google наука и Embase.

Результаты: Из общего количества 197 статей после оценки аннотаций или титульной страницы, было исключено 158 статей, которые не соответствовали критериям. Были рассмотрены полнотекстовые версии остальных 39 статей, а также библиографии и было добавлено ещё 5 статей в полнотекстовой версии.

Заключения: K настоящему времени ультразвуковое исследование считается самым надёжным методом пренатальной диагностики косолапости. Дагностика косолапости при помощи ультразвукового исследования является более вероятной между 18 и 24 неделями беременности. Альтернативный метод образной диагностики не указан. Нет единого мнения по вопросу необходимо ли фетальное кариотипирование, в случае диагностики изолированной косолапости при помощи пренатального ультразвукового исследования. Раннее установление косолапости должно стать основанием для внимательного наблюдения во время беременности с целью установления всех возможных сопутствующих аномалий. В случае установления подобных, необходимо предложить проведение инвазивной экспертизы. 